\title{
The Socio-Cultural Barriers Young Females Face in Accessing Technical and Vocational Education Training (TVET) in Rwanda.
}

\author{
Polycarpe Nshimirimana, Mary Damas Kitula
}

\begin{abstract}
The purpose of this study was to assess the socio-cultural factors that prevent females from accessing Technical and Vocational Education Training (TVET) in Rwanda. Females have been sensitized on the availability and benefits of TVET, to meet the required qualifications in order to be enrolled and yet the uptake of females to TVET remains low. The specific objectives of the study were to determine the socio-cultural factors that prevent girls from enrolling in TVET and establish the level of awareness of girls and parents about TVET and its benefits. The study answered why females are not embracing TVET as a promising avenue of education. The study used a case study strategy and applied both qualitative and quantitative approach (triangulation) at levels of data collection and analysis. The study used questionnaires, Focus Group Discussions (FGDs), Interviews and secondary data as data sources. The respondents included 400 females, parents and local leaders, TVET and integrated Polytechnic Regional Centers (IPRCs) staff for the Key Informant Interviews (KIIs). The research performed a simple linear regression analysis to find out predictor factors to enroll in TVET hence access to TVET that supplemented the correlation analysis. The findings of the study revealed social and cultural factors that prevent girls from enrolling in TVET include the belief that males have greater innate technical capacity than females and are thus predisposed to excel at programs with sciences and Mathematics backgrounds. Male Inheritance defined as investing in male for the continuity of the family, parent's belief of females' ineptitude at TVET labeled as male reserved areas, physical infrastructure variables such as distance from home to Training centers and female boarding facilities are additional factors which indicated a statistical significance with $p<0.001$. The study results indicated that the higher level of education of parents, the lower the enrolment of females in TVET Education. Many educated parents believe that TVET was for the failures and poor families. The study indicated that there was a discrepancy between the high expectations of enrolling in TVET prior to enrolling rated at $90 \%, 91.5 \%, 61.5 \%$, $84.5 \%, 79 \%$ compared to the actual benefits after enrolling rated at $32 \%, 37 \%, 50.5 \%, 62.0 \%, 54.5 \%$. The study showed the lack of information and underestimation of the value of TVET however increased access to information among females and parents led to increased enrolment of females in TVET schools.
\end{abstract}

Keywords: Access to TVET, Socio-Cultural Factors, Rwanda.

\section{INTRODUCTION}

For four decades, the song of women empowerment has been repeated since the 1980s, yet the journey is still long to go. Empowerment is a word that has been used so often and so widely that its definition has become blurred. (World Bank, 2002).

Revised Manuscript Received on August 13, 2020.

* Correspondence Author

Polycarpe Nshimirimana*, The Open University of Tanzania, Faculty of Arts and Social Sciences, Dar Es Salaam, Tanzania. E-mail: nshipoly@gmail.com

Mary Damas Kitula, Professor, The Open University of Tanzania, Faculty of Arts and Social Sciences, Dar Es Salaam, Tanzania. E-mail: marikitu@yahoo.co.uk

(C) The Authors. Published by Blue Eyes Intelligence Engineering and Sciences Publication (BEIESP). This is an open access article under the CC BY-NC-ND license (http://creativecommons.org/licenses/by-nc-nd/4.0/)
Carla Koppell, (2013) USAID Senior Coordinator for Gender Equality and Women's Empowerment wrote an article referring to President Obama, saying "if a country is educating its girls, if women have equal rights that country is going to move forward. Education is a silver bullet for empowering women and girls worldwide.

Michelle Obama (2014) revealed to 500 participants in President Barack Obama's Mandela Fellowship for Young African Leaders Initiative (YALI) summit about girls education that 62 million girls worldwide were not in school including 30 million girls in sub-Saharan Africa the issue was not focusing on the lack of resources needed in Africa and throughout the world to facilitate better schooling, the only concrete dialogue to have is on the attitudes parents and societies have about girls and women. This becomes a stumbling block to the females' enrolment in formal, technical and vocational education.

The vision of the Ministry of Education (MoE) is to transform the Rwandan citizen into skilled human capital for socio economic development by ensuring equitable access to quality education. (NISR,2013). However, if you look around today, women are woefully underrepresented in technical and vocational Educational training and this has been trending from short term training graduates to diploma level education.

Recent trends showed female participation was increasing when TVET was relegated to a less prestigious strand of education. (Harlt M, 2009), and this reflects the marginalization of females. There remains a divergence in the subjects studied by boys and girls: in 2009 only 36\% of pupils in mathematics and physics streams were girls. In technical subjects, the rates were $14 \%$ in electricity, $3 \%$ in general and automobile mechanics, and $7 \%$ in construction. Girls tend to select subjects that are more traditionally associated with female occupations, such as accounting (64\%) or secretarial (87\%). (Education Sector Strategic Plan, 2010)

The TVET policy (2008) indicated about 170,000 young people annually leave school without vocational preparation and continuing TVET capacities required by the labor market.

\section{THE PROBLEM STATEMENT AND OBJECTIVE}

Women were sensitized on the availability and benefits of TVET, women meet the required entry qualifications and yet the uptake of women to TVET remains low. Training institutions are in place and have space to accommodate trainees.

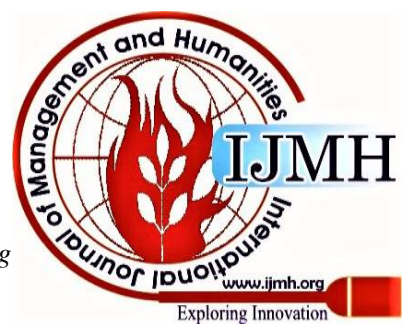


A big number of students complete nine years basic education but cannot be absorbed by formal Secondary schools. In 2011, the potential supply of nine years basic education to senior six leavers only $37 \%$ was enrolled (WDA, 2013). This showed that a big percentage was idle without skills making them unemployable. This figure was dominated by youth especially females. Despite all these opportunities being available, the enrolment rates of females in TVET remains low. The question is why don't females embrace technical and vocational skills?

The main purpose of the study was to assess the main socio-cultural factors that prevent girls from enrolling in Technical and Vocational Education Training in Rwanda. The study researched on what are the socio-cultural factors that prevent girls from joining TVET for life skills training?

Throughout the literature review, researchers consistently highlighted the low participation of females in technical education. The literature review did not answer what are the causes of the low enrolment? The aim of this study was to answer why females are not embracing TVET as a promising avenue of education as a pathway to gainful employment.

The study identifies the socio-cultural factors that prevent girls from enrolling in TVET in Rwanda.

\section{METHODOLOGY}

The study used a case study strategy and applied both qualitative and quantitative approach (triangulation) at levels of data collection and analysis. The study used questionnaires, Focus Group Discussions (FGDs), Interviews and secondary data as data sources. The respondents included 400 females, parents, local leaders,
TVET and Integrated Polytechnic Regional Centers IPRCs) staff for the Key Informant Interviews (KIIs).

The study used various analysis techniques including descriptive analysis comparing percentages of the variables under study that helped in long run to find out the relationship of the variables. The study performed a simple linear regression analysis to find out predictor factors to enroll in TVET hence access to TVET that supplemented the correlation analysis.

The Pearson Correlation Coefficient also called the Pearson's $r$ was used to measure the strength of the association or the linear relationship that exists between two or more continuous variables to be informed on their significant relationship. Coefficient values of this test were ranged from +1 to -1 , where +1 indicated a perfect positive relationship, -1 indicated a perfect negative relationship, and 0 indicated no relationship existed.

\section{THE FINDINGS}

\section{A. Social factors leading to the female enrolment to TVET Education}

The research examined factors mostly social termed as Independent Variables assumed to affect females' enrolment in TVET education termed the dependent variable henceforth access to TVET skills in Rwanda.

Parents' Level of Education

The question related to the level of education of female's parents had the assumption that the more they are educated the more their daughters will enroll in TVET education.

Table I. Parents Level of Education

\begin{tabular}{|c|c|c|c|c|c|}
\hline & & \multicolumn{2}{|c|}{ In TVET } & \multicolumn{2}{c|}{ Out of TVET } \\
\hline Variables & Description & Respondents & Percentage & Respondents & Percentage \\
\hline \multirow{4}{*}{$\begin{array}{c}\text { The level of } \\
\text { education of } \\
\text { parents }\end{array}$} & No formal education & 21 & 10.5 & 41 & 20.5 \\
\cline { 2 - 6 } & Primary (P1-P6) & 43 & 21.5 & 86 & 43.0 \\
\cline { 2 - 6 } & Post Primary (1-3 years) & 56 & 28.0 & 48 & 24.0 \\
\cline { 2 - 6 } & Tertiary/Technical training & 21 & 10.5 & 1 & 0.5 \\
\cline { 2 - 6 } & O level (S4-S6) & 35 & 17.5 & 10 & 5.0 \\
\cline { 2 - 6 } & Diploma & 11 & 5.5 & 2 & 1.0 \\
\cline { 2 - 6 } & Graduate & 11 & 5.5 & 5 & 2.5 \\
\hline
\end{tabular}

\section{Field study results (2016)}

The study revealed that parents whose girls are in TVET are generally more educated than parents whose girls are out of TVET schools. The study noted respectively parents whose girls are in TVET only $10.5 \%$ were without formal education versus $20.5 \%$ of parents whose girls were out of TVET almost a double. The study showed that $87.5 \%$ of parents whose girls were in TVET were educated to the level of nine years basic education against $60 \%$ of parents whose girls were out of TVET. Beyond nine basic education including Technical training the study showed 40 $\%$ of parents whose girls were in TVET had the education level to postgraduate compared to $12.5 \%$ of parents whose girls were out of TVET.

The study investigated if the level of education of parents had a correlation with the enrolment to TVET education.

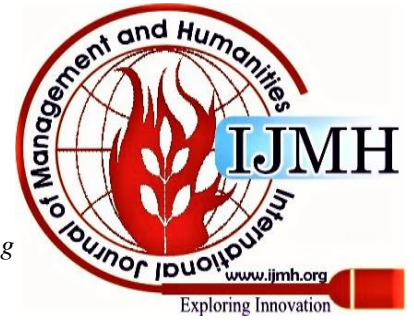


Table II. Correlation of Parent's Level of Education with Enrolment in TVET

\begin{tabular}{|c|c|c|c|}
\hline & & $\begin{array}{c}\text { Enrolment } \\
\text { status }\end{array}$ & $\begin{array}{c}\text { The level of education of } \\
\text { parents }\end{array}$ \\
\hline \multirow{3}{*}{ Enrolment status } & Pearson Correlation & 1 & $-.261 * *$ \\
\hline & Sig. (2-tailed) & & .000 \\
\hline & $\mathrm{N}$ & 400 & 400 \\
\hline \multirow{3}{*}{ The level of education of parents } & Pearson Correlation & $-.261 * *$ & 1 \\
\hline & Sig. (2-tailed) & .000 & \\
\hline & $\mathrm{N}$ & 400 & 400 \\
\hline
\end{tabular}

The level of education of Female's parents showed a correlation to the enrolment of females with a $\mathrm{p}<.001$ with a negative Pearson's coefficient of $\mathrm{r},-.261^{* *}$

The study explored whether the parents' level of education affected the female's enrolment to TVET education.

Table III. Regression Analysis test of Parent's Level of Education with Enrolment in TVET

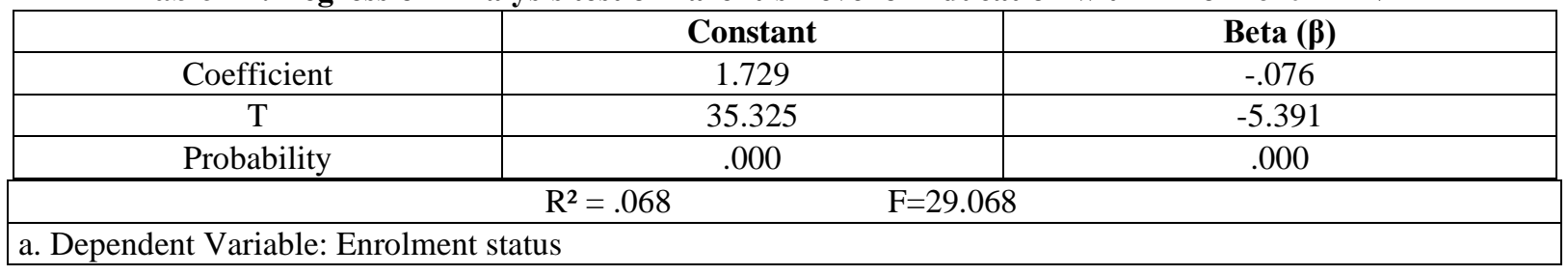

Field study results (2016)

The parents' level of education was statistically significant predictor of the enrolment of females in Technical Vocational Education Training, $\beta .-.076, \mathrm{t}(-5.391), \mathrm{p}<.001$, $\mathrm{R}^{2}=.068$

The results indicated that the higher the level of parents' education reduced the enrolment $(\mathrm{Y})$ of their females in the TVET Education as the above equation illustration.

The Focus Group discussions agreed on the negative perceptions that the TVET was the $2^{\text {nd }}$ best option in Education and fit to the failures. The parents with higher education prefer to send their children to the formal education expecting collar jobs therefore contributing to low enrolment rates in TVET education.

Parental belief of females' ineptitude at TVET programs In the social factors assumed to affect the female's enrolment the study noted the wrong parental attitudes towards girls' education was a limitation to the number of girls enrolling in TVET programs. The assumption was built on the belief that some social and cultural concepts hindering females from some non-traditional associated female occupations such as construction" ntamukobwa wurira inzu " meaning that its culturally prohibited to see a female climb buildings either in construction or repairing roof etc This limits girls' potential in that occupation and self-esteem towards development of competence ( selfactualization ) as re affirmed by the Focus Group Discussion in Nyamagabe District, Cyanika Sector. The question was to find out if that belief had a correlation to the enrolment of females in TVET Education. Below were the results:

Table IV. Parental Belief of Female's Ineptitude at TVET is a Continuing Stereotype

\begin{tabular}{|c|c|c|c|c|c|}
\hline & & \multicolumn{2}{|c|}{ In TVT } & \multicolumn{2}{c|}{ Out of TVET } \\
\hline Variables & Description & Respondents & Percentage & Respondents & Percentage \\
\hline $\begin{array}{c}\text { Parental belief of females' } \\
\text { ineptitude at TVET } \\
\text { programs }\end{array}$ & Agree & 101 & $50.5 \%$ & 26 & $13.0 \%$ \\
\cline { 2 - 6 } & Disagree & 99 & $49.5 \%$ & 174 & $87.0 \%$ \\
\hline
\end{tabular}

Field study results (2016)

$50.5 \%$ and $13 \%$ of the respondents in TVET and out of TVET respectively agreed to the statement that there was parental perception of females' ineptitude at taking on TVET programs. $49.5 \%$ and $87 \%$ of respondents in TVET and out of TVET disagreed with this statement.

The study investigated if there was any correlation between parental beliefs of females' ineptitude to excel at TVET and the female enrolment rates in TVET education. Below were the results: 
The Socio-Cultural Barriers Young Females Face in Accessing Technical and Vocational Education Training (TVET) in Rwanda.

Table V. Correlation of parents' beliefs of females' ineptitude at TVET subjects and females' enrolment in TVET

\begin{tabular}{|c|c|c|c|}
\hline & & $\begin{array}{l}\text { Enrolment } \\
\text { Status }\end{array}$ & $\begin{array}{l}\text { Parental belief of } \\
\text { female's inaptness in } \\
\text { TVET continuing } \\
\text { stereotype } \\
\end{array}$ \\
\hline \multirow{3}{*}{ Enrolment status } & Pearson Correlation & 1 & $-.403^{* *}$ \\
\hline & Sig. (2-tailed) & & .000 \\
\hline & $\mathrm{N}$ & 400 & 400 \\
\hline \multirow{3}{*}{$\begin{array}{l}\text { Parental belief of female's } \\
\text { ineptitude at TVET } \\
\text { programs }\end{array}$} & Pearson Correlation & $-.403^{* *}$ & 1 \\
\hline & Sig. (2-tailed) & .000 & \\
\hline & $\mathrm{N}$ & 400 & 400 \\
\hline
\end{tabular}

Source: Field study result (2016)

Parental belief of females' ineptitude at TVET correlated with female's enrolment in TVET. Results showed a statistical significance correlation of Parental belief of females' ineptitude at TVET and females' enrolment with a $\mathrm{p}<.001$ and a negative Pearson's correlation coefficient of r, -.403 .
The study investigated the simple linear regression analysis test of the parental attitude towards girls' education as Independent Variable with the female's enrolment to TVET education as dependent Variable with the assumption of finding a prediction equation of the linear regression of the two variables. The test results concluded the following:

Table VI. Regression Analysis Test of parents' beliefs of females' ineptitude at TVET programs as a continuing Stereotype and Enrolment of Females in TVET

\begin{tabular}{|c|c|c|}
\hline & Constant & Beta $(\beta)$ \\
\hline Coefficient & 1.782 & -.144 \\
\hline $\mathrm{T}$ & 45.181 & -8.779 \\
\hline Probability & .000 & .000 \\
\hline \multicolumn{3}{|c|}{$\mathrm{R}^{2}=.162$} \\
\hline
\end{tabular}

Field study results (2016)

The study noted that parent's belief of females' ineptitude at TVET programs was a significant predictor of the enrolment of females in Technical Vocational Education Training, $\beta$. -.403, t (-8.779), $\mathrm{p}<.001, \mathrm{R}^{2}=.162$.

The results also demonstrated a correlation between parental belief of females' ineptitude at TVET programs with female enrolment in TVET education $\mathrm{p}<.001, \mathrm{r}=-403$.

However, $\mathrm{R}^{2}=.162$ revealed that only $16.2 \%$ of the variation in dependent variable which was enrolment of female in TVET were explained by parental belief of females' ineptitude in TVET therefore new study need to consider more independent variables to the model.

During Focus Group Discussions one female revealed that she wanted to pursue Mechanical Engineering but when her parents found out, the parents strongly advised her to take on food processing, hairdressing because they have never seen a female mechanic and such a job requires muscle which they believed she did not have since they relate engineering profession with physical strength and not mental strength.

\section{B. Cultural Factors Affecting Female Enrolment in TVET Education}

To determine the cultural factors that prevent girls from enrolling in TVET, a set of questions were formulated and asked to female respondents in and out of TVET. The questions were articulated in statements for the six Independent variables such as early marriage for girls, chauvinistic male beliefs which perceived males as more important than females, males had more capacity to acquire technical skills especially in traditional male reserved areas "dealing with things" such as construction, welding, electricity, mechanics etc., girls fearing traditional male occupation , investing in males for the continuity of family, parental attitude towards girl education, Female roles termed as Reproductive "biological", Productive of labor, Provision and care of needs.

The research noted that out of six Independent Variables three indicated to be statistically significant with $\mathrm{p}<0.001$ while other three were not significant with $\mathrm{p}>.005$. Early marriage for girls, girls fearing traditional male occupation, female roles (Reproductive "biological", Productive of labor, Provision and care of children needs) didn't statistically ascertain the relationship with enrolment of females in TVET.

Beliefs in male's superior technical capacity compared to females in TVET

The chauvinistic male beliefs were built on the assumption that males are more important than females and have a higher capacity to acquire technical skills especially in traditional Male reserved areas "dealing with things" (construction, welding, electricity, mechanics etc).

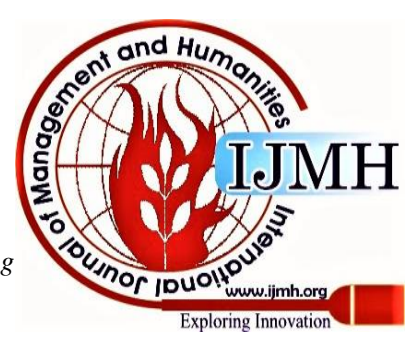


There was also a pre-dominant understanding that trades dealing with things were more paid and class than the ones dealing with people like tailoring, food processing etc therefore in period of limited capacity parents would prefer to enroll boys than girls hence decreased the enrolment of females in TVET Education.

Based on the respondents' results, 27\% (females in TVET) and 9\% (females out of TVET) agreed on the fact that there was a chauvinistic male belief that males were important than females in terms of acquiring technical skills particularly in the called "traditional male occupations dealing with things $73 \%$ females in TVET and $91 \%$ females out of TVET disagree on the statement of the chauvinistic male belief.

The study wanted to find out if there was any correlation of chauvinistic belief with female enrolment in TVET education. Here below are the results of the study:

Table VII: Correlation of Chauvinistic Male Beliefs and Enrolment of Females in TVET

\begin{tabular}{|c|c|c|c|}
\hline & & $\begin{array}{l}\text { Enrolment } \\
\text { status }\end{array}$ & $\begin{array}{l}\text { Beliefs in Male Inner Technical } \\
\text { Capacity than Female (chauvinistic } \\
\text { male beliefs) }\end{array}$ \\
\hline \multirow{3}{*}{ Enrolment status } & Pearson Correlation & 1 & $-.234^{* *}$ \\
\hline & Sig. (2-tailed) & & .000 \\
\hline & $\mathrm{N}$ & 400 & 400 \\
\hline \multirow{3}{*}{ 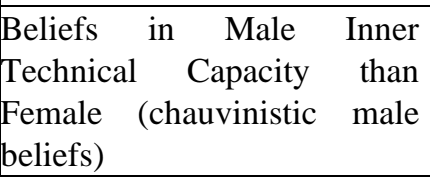 } & Pearson Correlation & $-.234^{* *}$ & 1 \\
\hline & Sig. (2-tailed) & .000 & \\
\hline & $\mathrm{N}$ & 400 & 400 \\
\hline
\end{tabular}

Field study results (2016)

The chauvinistic male belief correlated with female's enrolment in TVET, results showed a statistical significance correlation of the chauvinistic male belief to the enrolment of females with a $p<.001$ with a negative Pearson's coefficient of r, -.234

Table VIII: Regression Analysis Test of Chauvinistic Male Beliefs and Enrolment of Females in TVET

\begin{tabular}{|c|c|c|}
\hline & Constant & Beta $(\beta)$ \\
\hline Coefficient & 1.657 & -.102 \\
\hline $\mathrm{T}$ & 40.736 & -4.807 \\
\hline Probability & .000 & .000 \\
\hline \multicolumn{3}{|c|}{$\mathrm{R}^{2}=.055$} \\
\hline
\end{tabular}

\section{Field study results (2016)}

The study indicated that chauvinistic male beliefs statistically were significant predictor of the enrolment of females in Technical Vocational Education Training, $\beta$. $.234, \mathrm{t}(-4.807), \mathrm{p}<.001, \mathrm{R}^{2}=.055$

The study revealed a negative correlation which showed that an increase in the chauvinistic male beliefs in the community towards technical and Vocational education led to the decrease of female enrolment in TVET.

The chauvinistic male belief underrates females' capacity to perform in TVET education especially in the perceived "Male occupations". These negative perceptions limited the enrolment of females in TVET as mentioned by one of the TVET Trainers.

A significant number of the Focus Group Discussions revealed parents still held beliefs in males having greater innate Technical Capacity than females to pursue TVET courses labeled as male reserved areas dealing with things. The parents thought being male was prerequisite to have the ability to pursue sciences including Civil engineering (Construction), Electrical Engineering, Mechanics. These beliefs continued to increase the TVET stereotypes in labeled trades dealing with things considered to be higher paying compared to the labeled trades or occupation dealing with humanity labeled to be more female reserved including not limited to culinary arts, hairdressing, tailoring etc.
The female respondents refuted the fact of males had more ability in courses requiring prerequisite of sciences. However, the female respondents recognized some females had less confidence to pursue trades such as Civil engineering, Electrical engineering and Mechanical engineering that may have roots in cultural beliefs. Females irrespective of being in TVET or out of TVET still experienced the wrong belief of underestimating women's capacity in the "traditional Male reserved occupations/ professions. The respondents also stated that in cases of limited capacity, parents would prefer to enroll boys than girls hence decreased the enrolment of females in TVET Education.

One of the male parents said "Though there is a mass campaign of our daughters to register in TVET, I believe that females fit better in occupations dealing with humanity such as tailoring, culinary arts, hairdressing whereas males fit better in occupations dealing with mechanics carpentry, construction etc. He added this started from the way males and females were created. We should respect them as they are."

Published By:

Blue Eyes Intelligence Engineering \& Sciences Publication (C) Copyright: All rights reserved.

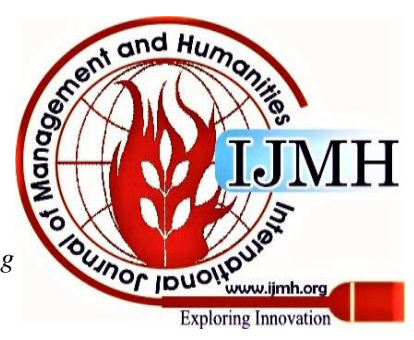




\section{Male Inheritance in the Continuity of the Family}

Investing in males for the continuity of the family was constructed on the assumption that culturally parents believed that females got married and joined the husband's family rather than their biological parents. The belief was also reinforced by the patriarchal system in which men have more power than women therefore men have some privileges women are not entitled to. Parents therefore strongly believe in investing in males who will support elderly parents. The assumption is also that after the parents' death, the male's inheritance will continue to support their siblings rather than females. The belief is based on the social economic support structure where parents before received support from their married sons compared to daughters. Parents investments in female education does not pay off the same way as the job remuneration benefits are enjoyed by the husband's family rather than their biological parents compared to their counterpart males.

Based on female respondents $31 \%$ in TVET and $12 \%$ out of TVET agreed on the statement that parents believed that investing in male rather than female in TVET is more rewarding for parents. However, $69 \%$ in TVET and $88 \%$ out of TVET disagreed with this statement.

Table IX. Correlation of Male Inheritance with Female's Enrolment in TVET

\begin{tabular}{|c|c|c|c|}
\hline & & Enrolment status & Male Inheritance \\
\hline \multirow{3}{*}{ Enrolment status } & Pearson Correlation & 1 & $-.231^{* *}$ \\
\hline & Sig. (2-tailed) & & .000 \\
\hline & $\mathrm{N}$ & 400 & 400 \\
\hline \multirow{3}{*}{ Male inheritance } & Pearson Correlation & $-.231^{* *}$ & 1 \\
\hline & Sig. (2-tailed) & .000 & \\
\hline & $\mathrm{N}$ & 400 & 400 \\
\hline
\end{tabular}

\section{Source: Field study result (2016)}

The study showed that investing in male for the continuity of the family correlated with female's enrolment in TVET, results showed a statistical significance correlation of Investing in male for the continuity of the family correlated with female's enrolment in TVET with a $\mathrm{p}<.001$ and a negative Pearson's correlation coefficient of $\mathrm{r},-.231$

Table X. Linear Regression Analysis Test of Male Inheritance and Enrolment in TVET

\begin{tabular}{|l|l|l|}
\hline & Constant & Beta $(\boldsymbol{\beta})$ \\
\hline Coefficient & 1.654 & -.094 \\
\hline $\mathrm{T}$ & 40.681 & -4.742 \\
\hline Probability & .000 & .000 \\
\hline \multicolumn{2}{|c|}{$\mathrm{R}^{2}=.052$} & $\mathrm{~F}=22.485$ \\
\hline \multicolumn{2}{|c|}{} \\
\hline \multicolumn{2}{|c|}{ a. Dependent Variable: Enrolment status } \\
\hline
\end{tabular}

\section{Source: Field study results (2016)}

The study indicated that investing in male for the continuity of the family was statistically significant predictor of the enrolment of females in Technical Vocational Education Training, $\beta$. -.094, t (- 4.742), $\mathrm{p}<.001$, $\mathrm{R}^{2}=.052$.

The increased belief in investing in male for the continuity of family decreased enrolment of females in TVET.

During Focus Group Discussions with parents, views were divided as to whether the male inheritance for the continuity of the family held true and affected the enrolment rates. Rwanda's laws provide opportunities for gender equity by granting equal inheritance rights to sons and daughters and protection of a surviving spouse and children's rights to property. However, customary systems continue to govern family and land matters and often discriminate against women's direct rights to property and inheritance (Cooper E., 2011). Inheritance is a major means for the transfer, or exclusion from the transfer, of people's accumulated physical capital. The transfer of physical assets from the parent to the child generation can provide the start-up material for the younger generation's more independent future livelihoods and economic productivity (Fafchamps and Quisumbing, 2005). However, exclusion from assets inheritance can exacerbate vulnerability to chronic poverty and the intergenerational transmission of poverty (Bird et al., 2004). The context of Rwandan Law has given equal rights to female and male in terms of inheritance from their parents' however the belief of male inheritance for the family's continuity still holds as attested by several parents discussed in the Focus Group. Parents were asked who they would educate if resources were limited, boys versus girls. One of the mothers responded: "I would educate the boy".

The justification for this choice is normally boys get married later than girls therefore the income from TVET job would support the household longer than girls' incomes would. She added: "Husbands have more access to household income including inheritance compared to wives" therefore she continued: "I would receive more support from my son".

She believes even in her old age or after her death, the son will responsibly support his siblings compared to girls.

Published By:

Blue Eyes Intelligence Engineering \& Sciences Publication (C) Copyright: All rights reserved.

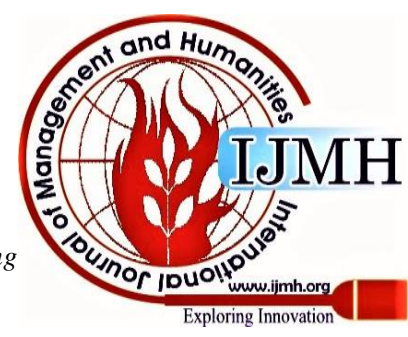


The parents' votes were not unanimous, and parents concluded the decision as to who to send to school in case of limited resources was not an obvious choice and the decision would take into account other variables for example distances to the Training Centers, programs available, required tuition etc.

Both categories of female respondents (those in TVET or those out of TVET) Focus Group Discussions revealed when resources are limited, the tendency remains to send boys.

\section{DISCUSSION AND CONCLUSION}

Rena, R (2007) conducted a study on Factors Affecting the Enrollment and the Retention of Students at Primary Education in Andhra Pradesh - A Village Level Study. The study found that the educational level of the parents of the never enrolled and dropped out children reveals that they are mostly illiterate and some who have studied only till upper primary education (VII and below). Thus, the education of the parents is also found to be an obstacle in the way of the education of children. This study was in alignment with parents to be an obstacle to the education of girls in TVET in the contrast where the higher level the parent's education the lesser their girls enroll in TVET since TVET was labeled as second-best education. The study noted the wrong parental attitudes towards girls 'education as a limitation to the number of girls enrolling in TVET programs. The study also indicated a negative correlation which showed that an increase in the parental belief of females' ineptitude at TVET programs translated into negative parental attitude towards girl education resulting in lower enrolment of females in TVET.

Parents' beliefs hindered females from joining nontraditional female occupations such as construction. This limits girls' potential in that occupation and self-esteem towards development of competence (self-actualization) as re affirmed by the Focus Group Discussion in Nyamagabe District, Cyanika Sector.

These findings are in line with Huitt, W. (2007) and Abraham Maslow (1954)'s research work related to human growth and personal development also referred to as theories of human motivation. The theory on its third ladder talked on achievement of self -actualization at the top of the pyramid which can be attained through education. The parental belief of females' ineptitude at TVET programs particularly non-traditional associated female occupations such as construction, mechanics continued to increase TVET stereotypes leading to the decreased enrolment in TVET education. Societal belief of females' ineptitude in TVET programs has a negative implication on girls/ women self-confidence, demotivates them thus female achievement of self-actualization is compromised.

The study tested cultural factors as independent variables presumed to positively or negatively affect female's enrolment in TVET education termed the dependent variable henceforth access to TVET skills in Rwanda. The study contributed cultural variables that motivate negatively the enrolment of females in TVET.

Male innate technical capacity compared to females (chauvinistic male beliefs): The results indicated that the increase in level of chauvinistic male belief implicated the decrease enrolment of females in the TVET Education. During Focus Group Discussions, many parents still believe in males having greater inner technical capacity compared to females to take on TVET courses labeled as male reserved areas dealing with things. Several Females in TVET and out of TVET Focus Group Discussions disagreed with the statement of the chauvinistic male beliefs built on the assumption that males were important than females based on the inner capacity to acquire technical skills. One female student said: "I have always got good marks in sciences more than my counterparts' student males. I do not see the evidence of sex difference in technical inner capacity".

However, the female respondents acknowledged some females have less confidence to pursue trades such as Civil engineering, Electrical engineering and Mechanical engineering that may have roots in cultural beliefs.

RUBAGIZA, (2010) in her research, TVET Policy in Rwanda Gender Analysis of the Technical Vocational Education and Training Forum for African Women Educationalists (FAWE Rwanda), the analysis took on the social relations approach as 'a method of analyzing the gender inequalities within institutionalized relations that affect the distribution of resources, responsibilities, and power'. Her research mentioned views that expressed caution on 'pushing' girls or even boys in the so-called nontraditional areas offering scholarships where later the recipients may not join those professions, either because there are no jobs readily available or because the stereotypes continue to exist.

Thompson, Grace and Cohen (2001) state the most important needs for children are connection, recognition, and power.

Thompson, Grace and Cohen (2001), Rubagiza (2010) all agreed on the fact of recognition and power which is in the alignment of the work of (Maslow \& Lowery, 1998) culminating to the growth needs as part of the more general level of self-actualization. The research indicated that not recognizing the girl's capacity in technical subjects especially parents and society in general, cultural belief of more inner capacity of male than female demotivates the latter for the self-actualization of her competence.

Male inheritance in the continuity of the family: The results indicated higher belief in investing in male for the continuity of family implicated the reduction of enrolment of females in the TVET Education.

Baden, S \&Milward K, (1997) stated that female's disadvantages in enrolment is thus not simply a matter of overall development. Factors such as social and cultural attitudes, and policy priorities are clearly also significant.

Though the context of Rwandan Law has given equal rights to females and males in terms of inheritance from their parents, many parents stated: "The belief of male inheritance for the continuity of the family has never died".

Though there were divided responses, some parents agreed priority is given to boys rather than girls when there is scarcity of resources but with adequate resources, either gender has an opportunity to pursue education.

Richard (2005) found that there were large differences in women's and men's preferences for realistic occupations (for example, mechanic or carpenters) and moderate differences in their preferences for social and artistic occupations.

Published By:

Blue Eyes Intelligence Engineering \& Sciences Publication (C) Copyright: All rights reserved.

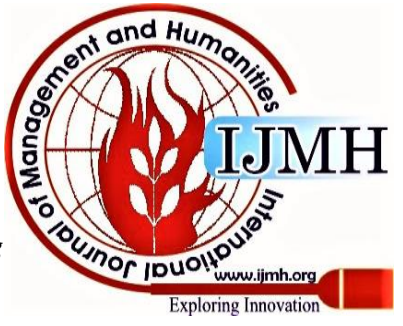


His results also found that women tended to be more people-oriented and men more thing-oriented.

\section{REFERENCES}

1. $\quad$ Bird, K., Pratt, N., O’Neil, T., \& Bolt, V. (2004). Fracture Points in Social Policies for Chronic Poverty Reduction'. Working Paper 242. London: Overseas Development Institute (ODI) and Chronic Poverty Research Centre (CPRC). Retrieved from http://www.chronicpoverty.org/ uploads/publication files/WP47 Bird et al.pdf

2. Carla, K. (2013). Educate Girls, Develop Nations [Blog post] Retrieved from http://blog.usaid.gov/2013/04/educate-girls-developnations/.

3. Cooper, E. (2011). Challenges and opportunities in inheritance rights in Rwanda: policy notes. Chronic Poverty Research Centre Retrieved from https://www.Rwandan Family law provision on Parents inheritance Chronic Poverty Research Center

4. Fafchamps, M. \& Quisumbing, A. (2005). Assets at Marriage in Rural Ethiopia. Journal of Development Economics, 77, 1- 25.

5. HARTL, M. (2009, April). Technical and vocational education and training (TVET) and skills development for poverty reduction - do rural women benefit? Paper presented at the FAO-IFAD-ILO Workshop on Gaps, trends and current research in gender dimensions of agricultural and rural employment: differentiated pathways out of poverty.

6. Huitt, W. (2007). Maslow's hierarchy of needs. Educational Psychology Interactive. Valdosta, GA: Valdosta State University. 189 pp

7. Government of Rwanda, (2012). Rwanda Vision 2020, revised 2012 July (2000). Pp 40

8. National Institute of Statistics of Rwanda, (2013). Statistical yearbook 2012. Government printer, Kigali, Rwanda. Pp 154

9. Rena, R. (2007). Factors affecting the enrollment and the retention of students at primary education in Andhra Pradesh - a village level study. Essay in Education UGSM Monarch Business School, 1, (22), 28, 102-112 pp.

10. RUBAGIZA, J. (2010). Gender Analysis of the Technical and Vocational Education and Training (TVET Policy) in Rwanda. FAWE printer, Kigali, Rwanda. 29pp

11. Richard, L. (2005) Female Psychology Gender, Nature, and Nurture, Psychology Press; 2 edition (March 11, 2005)

12. World Bank, (1990). World Development Report: Poverty World Development Indicators. World Bank, Oxford, London. 276pp

\section{AUTHORS PROFILE}

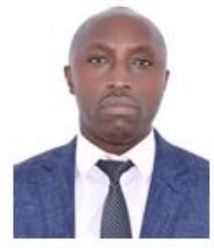

Polycarpe Nshimirimana, is a Public Private Partnerships Expert prior He was a part time lecturer Module Leader at University of Rwanda 2012-2014 in Management of Development Projects. He is pursuing PhD in Faculty of Arts and Social Sciences with Open University of Tanzania. He pursues the growth of knowledge in the discipline of Technical and Vocational Educational Training (TVET).

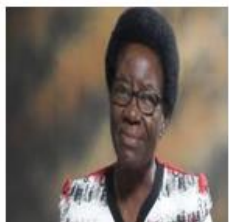

Mary Damas Kitula, (Professor) BA (Ed), MA (Demography) UDSM; PhD (Sociology, Demography and Environment). Senior lecturer at the Open University of Tanzania, She is a coordinator for master's Program Gender Studies at Open University of Tanzania

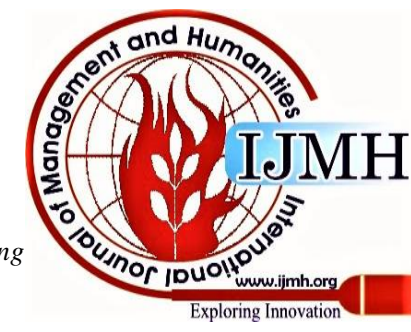

